\title{
(ㄷ)
}

Research Paper

EPRA International Journal of Economic and Business Review-Peer Reviewed Journal

Volume - 9, Issue - 6, June 2021 | e-ISSN: 2347 - 9671| p- ISSN: 2349 - 0187

SJIF Impact Factor (2021): 8.302 || ISI Value: 1.433 || Journal DOI URL: https://doi.org/10.36713/epra2012

\section{EXTENT OF PARTICIPATION OF RURAL WOMEN IN FISHING COMMUNITY: APPROACHES TOWARD SUSTAINABLE LIVELIHOOD}

\author{
Fedelyn S. Ibarra \\ Julita Elementary School, Libacao, Aklan Philippines
}

\begin{abstract}
DOI No: 10.36713/epra7406

Article DOI URL: https://doi.org/10.36713/epra7406
\end{abstract}

\begin{abstract}
Women's contribution to small-scale fishing community is often unrecognized and the real benefits from their involvement in activities are not objectively assessed. This qualitative research study focuses on the women's participation in fishing community in Aklan. The findings revealed that in most fishing activities, women's role is significant. Women's participation in fishing includes: net mending, sorting fish, fish vending, trading and market retailing and processing and preservation. Women also have been found directly involved in preparing cage and maintenance, procuring good quality seed, and stocking. Some women are also found to be selling fish on their own, and most vend by the public market and streets. Fishing is an occupation dominated by men because of the image that only men go to sea in their fishing boats. In most cases, women in fishing communities are not allowed to go with the fishing vessels, but this prohibition is tied mostly to the need for them to remain within the premises of the household so they can attend to their designated responsibilities in the home. Due to this, they have little direct involvement in fish capture. However they are involved in shell and fry gathering/gleaning, spear fishing in rivers, reef fishing using scoop nets, traps and fish baskets, all of which tend to be near-shore activities. Women's participants' family income has increased which is mostly used for food, health, and education as a very important positive aspect of change. Women's participation in fishing community, according to the findings, ensures certain extent of social and economic empowerment in the rural societies. However, they expressed that they would like to sustain through bank and NGO loan, local moneylender and petty cash personal savings.
\end{abstract}

KEY WORDS: Fishing Community, Income, Participation, Rural Women, Sustainable Livelihood

\section{INTRODUCTION}

The Philippines is a world-significant fish producer, ranking eleventh among the 80 fish producing countries of the world. The fishing industry contributed $3.8 \%$ to total GDP and $18.6 \%$ to GVA in the agriculture industry group, valued at P34 billion (constant prices). The importance of this sector is emphasized by the fact that fish is the major source of animal protein in the diet of the average Filipino, and constitutes $12 \%$ of total annual food intake (IM Siason, 2000)

Women make up at least half of the inland fisheries' workforce, with $60 \%$ and $80 \%$ of seafood 
marketed by women in Asia and West Africa (FAO 2012). Women in West Africa, Cambodia and Thailand often own and manage fishing boats and may even have their own fishing gear. In Ghana, income from fisher's wives is vital for supporting the entire fishing industry, as they invest in canoes and other gear and give out loans to husbands and other fishers. Fisherwomen in the Congo, Cambodia, Thailand, the Philippines, and most of the South Pacific islands, contradict the perceived role of females as gleaners only.

Fishing has long been considered a male dominated occupation and women were thought to be involved only in post-harvest activities. However, there is a growing recognition of women's contribution in capture fisheries in all activity spheres. In China, rural labor force statistics for 1991 showed that women accounted for $26.3 \%$ of the rural labor force in fisheries (UNDP/FAO, n.d. quoted in FAO/SD website 1).

In Asia, women are active in both artisanal and commercial fisheries. In parts of India, women net prawns from backwaters; in Lao PDR they fish in canals; in the Philippines, they fish from canoes in coastal lagoons (FAO/Gender in Fisheries website 2). In areas where male migration is prevalent, women are bearing heavier responsibility in fisheries (Suwanrangsi, n.d.) and with the feminization of fisheries; women's roles in fisheries and aquaculture are becoming increasingly important.

On the other hand, women have also assumed a leading role in the rapid growth of aquaculture (fish, shrimps, mussel, seaweed, crab fattening), with their participation along the aquaculture value chains (production, transforming, and marketing) resulted to higher family income.

Studies on women in fisheries so far have been more or less concentrated on fish processing and preservation techniques and activities, extension, and socio-economic status of women (Vega, 1989) and on women's participation in fisheries or in aquaculture (Harrison, 2000). There has been less focus on looking into gender relations or examining how gender relations in the household and community affect fisheries related activities. That is, women's activities have been treated as separate activities and the complimentary and conflicting roles and relations between women and men have been given little attention (Harrison, 2000), hence this study.

\section{METHODOLOGY}

\section{The Research Design}

This qualitative study chose content analysis as the most appropriate method specific for this purpose. According to Neuendorf (2002), content analysis is the summarizing, quantitative analysis of messages that relies on the scientific method (including attention to objectivity, intersubjectivity, a priori design, reliability, validity, generalisability, replicability, and hypothesis testing) and is not limited as to the types of variables that may be measured or the context in which the messages are created or presented.

Key informant (KI) interviews were conducted to gather qualitative information and to triangulate findings. The strength of qualitative research is its ability to provide complex textual descriptions of how people experience a given research issue. It provides information about the "human" side of an issue - that is, the often contradictory behaviors, beliefs, opinions, emotions, and relationships of individuals. Qualitative methods are also effective in identifying intangible factors, such as social norms, socioeconomic status, gender roles, ethnicity, and religion, whose role in the research issue may not be readily apparent. When used along with quantitative methods, qualitative research can help us to interpret and better understand the complex reality of a given situation and the implications of quantitative data.

Findings from qualitative data can often be extended to people with characteristics similar to those in the study population; hence, gaining a rich and complex understanding of a specific social context or phenomenon typically takes precedence over eliciting data that can be generalized to other geographical areas or populations.

\section{The Respondents}

The respondents in this study were 30 rural women in some selected areas of Aklan. The respondent's age is above 18 years old.

\section{Data Gathering Tool}

An interview guide was used to derive information from the participants during the KI interviews. A mini-cassette recorder was utilized while interviews were conducted. Field notes were also kept by the researcher to keep track of the discussions conducted.

\section{Data Gathering Procedure}

A written permit to address to the Punong Barangay was secured before the actual survey was conducted. After establishing the report, KI interviews were conducted. In these activities, participants were briefed that all information they would provide would be dealt with utmost confidentiality. This assurance was given so that spontaneity of answers would be gathered as participants were assured that their identities would, at whatever instance, never be divulged.

\section{Ethical Consideration}

Ethical considerations of this study have been effectively addressed. The research participants were 
informed of aims and objectives of the study before the primary data collection process. No participant was coerced or deceived to take part in this study. The privacy of the research participants were also ensured as no personal data were collected from them. Therefore, the researcher obtained the informed consent of participants prior to their involvement in this study.

\section{Data Analyses}

Tabulation of data was done directly from the document to minimize time and effort. The data and other information gathered were grouped, categorized and analyzed according to the objectives of the study. Relevant answers during the KI activities were directly quoted in their original form (with equivalent English translations as necessary).

The mean ratings of each indicator of the extent of women participation in fishing activities were described using the scale below:

$$
\begin{aligned}
& 4.50-5.00-\text { Very Often } \\
& 3.50-4.49-\text { Often } \\
& 2.50-3.49-\text { Seldom } \\
& 1.50-2.49-\text { Rarely } \\
& 1.00-1.49-\text { Not at all }
\end{aligned}
$$

\section{PRESENTATION, ANALYSIS AND INTERPRETATION OF DATA}

Table 1 shows the distribution of respondents according to the duration of their participation in fishing activities. The data revealed that 15 or fifty percent participated in fishing activities below 5 years, 9 or 30 percent for two years participation and 6 or 20 percent for eleven years and above. This implies that women were directly involved in fishing activities.

Table 1. Distribution of Respondents according to the number of years of participation in fishing activities

\begin{tabular}{|l|c|c|}
\hline \multicolumn{1}{|c|}{ Number of Years } & Frequency (N= 30) & Percentage (\%) \\
\hline Below 5 years & 15 & 50.00 \\
\hline 6-10 Years & 9 & 30.00 \\
\hline 11 \& Above & 6 & 20.00 \\
\hline Total & 30 & 100.00 \\
\hline
\end{tabular}

Table 2 presents the distribution of respondents by their extent of participation in fishing activities. As shown in table 2, the activities participated in by women are sorting fish with 10 or 33.33 percent, followed closely by fish vending with 9 or 30 percent, net mending 7 or
23.33 per cent, 3 or 10 percent in fish processing and preservation and only 1 or 3.33 percent in trading and market retailing. This means that rural women in aklan participated in various fishing activities.

Table 2. Distribution of Respondents according to their participation in fishing activities

\begin{tabular}{|l|c|c|}
\hline \multicolumn{1}{|c|}{ Fishing Activities } & Frequency (N= 30) & Percentage (\%) \\
\hline Net Mending & 7 & 23.33 \\
\hline Sorting Fish & 10 & 33.33 \\
\hline Fish Vending & 9 & 3.00 \\
\hline Trading and Market Retailing & 1 & 10.00 \\
\hline Processing and Preservation & 3 & \\
\hline
\end{tabular}

Shown in table 3 is the knowledge and skills of the respondents in fisheries maintenance. Results showed that the knowledge and skills in fisheries of rural women such as management and time of harvesting got mean ratings of 4.96 and 4.5 respectively. On the other hand, knowledge and skills of the respondents in terms of identification of good quality seed, stocking density, cage and maintenance and time of stocking were rated by the respondents as often. The grand mean of 4.08 denotes often practiced by the respondents. 
SJIF Impact Factor (2021):8.302 || DOI: 10.36713/epra2012 | Volume-9 | Issue-6 | June 2021 | e- ISSN: 2347-9671 | p- ISSN: 2349-0187

Table 3. Distribution of respondents according to the knowledge and skills in fisheries management.

\begin{tabular}{|c|c|c|c|c|c|c|c|}
\hline \multirow{2}{*}{$\begin{array}{c}\text { Knowledge and Skills in Fisheries } \\
\text { Maintenance }\end{array}$} & \multicolumn{5}{|c|}{ Extent of Participation } & \multirow[t]{2}{*}{ Mean } & \multirow[t]{2}{*}{ Interpretation } \\
\hline & $\begin{array}{c}5 \\
\text { Very Often } \\
\text { F WF }\end{array}$ & $\begin{array}{c} \\
\text { Often } \\
\text { F WF }\end{array}$ & $\begin{array}{c}3 \\
\text { Seldom } \\
\text { F WF }\end{array}$ & $\begin{array}{c}2 \\
\text { Rarely } \\
\text { F WF }\end{array}$ & $\begin{array}{c}1 \\
\text { Not at all } \\
\text { F WF }\end{array}$ & & \\
\hline Cage and Maintenance & $10 \quad(50)$ & $2(8)$ & $18 \quad(54)$ & & & 3.73 & Often \\
\hline Identification of Good Quality Seed & $10 \quad(50)$ & $8 \quad(32)$ & $12(36)$ & & & 3.93 & Often \\
\hline Time of Stocking & $5 \quad(25)$ & $10 \quad(40)$ & $10 \quad(30)$ & $5(10)$ & & 3.5 & Often \\
\hline Stocking Density & $8 \quad(40)$ & $1040)$ & $1236)$ & & & 3.86 & Often \\
\hline Management & $19(95)$ & $3(12)$ & $8 \quad(24)$ & & & 4.96 & Very Often \\
\hline Time of Harvesting & $16(80)$ & $13(52)$ & $1 \quad(3)$ & & & 4.5 & Very Often \\
\hline Grand Mean & & & & & & 4.08 & Often \\
\hline
\end{tabular}

Legend:

$$
\begin{aligned}
& \text { F }- \text { Frequency } \\
& \text { WF }- \text { Weighted Frequency } \\
& 4.50-5.00 \text { - Very Often } \\
& 3.50-4.49 \text { - Often } \\
& 2.50-3.49 \text { - Seldom } \\
& 1.50-2.49 \text { - Rarely } \\
& 1.00-1.49 \text { _ Not at all }
\end{aligned}
$$

Table 4 presents the distribution of respondents according to their participation in vending fish. Results

\begin{tabular}{|c|c|c|c|c|c|c|c|}
\hline \multirow{3}{*}{ Selling Places } & \multicolumn{5}{|c|}{ Extent of Participation } & \multirow[t]{3}{*}{ Mean } & \multirow[t]{3}{*}{ Interpretation } \\
\hline & $\begin{array}{c}5 \\
\text { Very Often }\end{array}$ & $\begin{array}{c}4 \\
\text { Often }\end{array}$ & $\begin{array}{c}3 \\
\text { Seldom }\end{array}$ & $\begin{array}{c}2 \\
\text { Rarely }\end{array}$ & $\begin{array}{c}1 \\
\text { Not at all }\end{array}$ & & \\
\hline & $\mathbf{F} \quad \mathbf{W F}$ & $\mathbf{F} \quad \mathbf{W F}$ & $\mathbf{F} \quad \mathbf{W F}$ & F WF & $\mathbf{F} \quad \mathbf{W F}$ & & \\
\hline Public Market & $16(80)$ & $10(40)$ & $4 \quad(12)$ & & & 4.40 & Often \\
\hline Selling Directly (Galibot) & $17 \quad(85)$ & $\begin{array}{ll}6 & (24)\end{array}$ & $7(21)$ & & & 4.33 & Often \\
\hline Middle Man & $5 \quad(25)$ & $10(40)$ & $10(30)$ & $5(10)$ & & 3.50 & Often \\
\hline Grand Mean & & & & & & 4.07 & Often \\
\hline
\end{tabular}
showed that most of the respondents vend fish through public market, some sell fish through direct selling with limited number of respondents sell fish through middle man with a mean rating of 3.50. This implies that the extent of participation of rural women in selling is high.

Table 4. Distribution of respondents according to their extent of participation in selling places.

\section{Legend:}

$$
\begin{aligned}
& \text { F - Frequency } \\
& \text { WF - Weighted Frequency } \\
& 4.50-5.00-\text { Very Often } \\
& 3.50-4.49-\text { Often } \\
& 2.50-3.49-\text { Seldom } \\
& 1.50-2.49-\text { Rarely } \\
& 1.00-1.49 \text { _ Not at all }
\end{aligned}
$$


Table 5 shows the distribution of respondents according to economic profile. The data revealed that majority of the respondents (14 or 46.67 per cent) has monthly income bracket of 500.00 to $1,000.00$ pesos. This means that monthly income of the respondents were below the poverty threshold level.

Table 5: Economic Profile of the Respondent

\begin{tabular}{|c|c|c|}
\hline Monthly Income & Frequency $\mathbf{( N = 3 0 )}$ & Percentage (\%) \\
\hline $500.00-1000$ & 14 & 46.67 \\
\hline $1001-3,000$ & 8 & 26.67 \\
\hline $3,001-5000$ & 6 & 20.00 \\
\hline Above 5,001 & 2 & 6.66 \\
\hline Total & 30 & 100.00 \\
\hline
\end{tabular}

Table 6 shows the initial investment of the respondents, 12 or 40.00 percent were through money lender, 10 or 33.33 per cent were NGO loan, 6 or 20.00 per cent were personal savings and 2 or 6.67 per cent were bank loan.

Table 6: Initial Investment

\begin{tabular}{|l|c|c|}
\hline \multicolumn{1}{|c|}{ Initial Investments } & Frequency $(\mathbf{N = 3 0})$ & Percentage \\
\hline Personal Savings & 6 & 20.00 \\
\hline NGO Loan & 10 & 33.33 \\
\hline Bank Loan & 2 & 6.67 \\
\hline Money Lender & 12 & 40.00 \\
\hline Total & 30 & 100.00 \\
\hline
\end{tabular}

\section{SUMMARY, CONCLUSIONS AND RECOMMENDATIONS SUMMARY}

This qualitative research study was purposely conducted to find out the extent of fishing activities among rural women in Aklan Philippines. It also tried to find out the knowledge and skills in fisheries management, venue of selling fish, economic profile and initial investment of the respondents.

\section{CONCLUSIONS}

Women who are the subject of this study are generally poor, and high school level. The majority belongs to small cultivator or tenant households. Many work as wage laborers on a part time or seasonal basis usually employed by large landowners and generally receive payment in less than their male counterparts. Despite being the de facto managers of the household, women's view in the decision-making are recognized. Women's dependence on men within the family and on the extended family is reinforced by asymmetrical rules of inheritance.

\section{RECOMMENDATIONS}

Training on livelihood sustainability.

The concerned government agencies must provide additional financial support to rural women engaged in fishing activities.

\section{REFERENCES}

1. Ahmed, Mahfuzuddin, Hap Navy, Ly Vuthy and Matites Tiongco (1998). Socioeconomic assessment of freshwater capture fisheries of Cambodia: Report on a household survey, Mekong River Commission, Phnom Penh, Cambodia.

2. Ahmed, Khan Kamaluddin, Sanzidur Rahman and M.A. Kabir Chowdury (1999). Role of tribal women in reservoir fisheries of Bangladesh, Aquaculture Asia, January-March, Vol. IV, No.1, pp.12-15.

3. Coates, David (2002). Inland capture fishery statistics of Southeast Asia: Current status and information needs, Asia-Pacific Fishery Commission, Food and Agriculture Organization of the United Nations, Regional Office for Asia and the Pacific, Bangkok, Thailand.

4. CIRDAP's Action Program (1989). Rural women in fishing communities, Naga, The ICLARM Quarterly, pp. 10-12, April.

5. Dehadrai, P.V. (1992). Opportunities for women in rice-fish culture in C.C.R. dela Cruz, B.A. Lightfoot, V.R.Costa-Pierce, Carangal and M.P. Bimbao (eds.) Rice-fish research and development in Asia _24, ICLARM, Manila, pp. 67-372.

6. Elson, Diane (1992). Male bias in structural adjustment, in Women and adjustment policies in the Third World, Macmillan.

7. FAO (1995). Women, agriculture and rural development: National sectoral report for the Philippines, prepared under the auspices of FAO's programme of assistance in support of rural women in preparation of the Fourth World Conference of Women, FAO, Rome.

8. Goetz, Anne Marie (1997). Introduction: Getting institutions right for women in development, In 
Anne Marie Goetz (ed.) Getting institutions right for women in development, Zed Books, London.

9. Harrison, Elizabeth (2000). Gender, rights and poverty issues: Lessons for the sector, Background paper for DFID/FGRP-3/ARP Workshop on practical strategies for poverty targeted research, 7-11 November, Overseas Development Institute.

10. Kusakabe, Kyoko (1999). Women's participation in the market: A case study of women retail traders in Phnom Penh, Cambodia, Ph.D. dissertation, Asian Institute of Technology.

11. Kusakabe, Kyoko and Govind Kelkar (ed.) (2001). Gender concerns in aquaculture in Southeast Asia, Gender Studies Monograph 12, Gender and Development Studies, Asian Institute of Technology, Thailand.

12. Seyha, Rin, Po Samang, Sous Thida, and Tony Knowles (2001). Preliminary field assessment and observations of commercial freshwater fishery operations around the Tonle Sap Lake, Draft Report, Enterprise Development Cambodia.

13. Sothirak, Sok (2002). Micro-scale border trade of in-land fish: A case study of borderland in Poipet, Cambodia and Aranyaprathet, Thailand, final report on comprehensive capacity building for sustainable development in the Greater Mekong Sub-region, Asian Institute of Technology.

14. Suwanrangsi, Sirilak (n.d.) Technological changes and their implications to women in fisheries, unpublished paper.

15. Vega, Marcos Jose M. (1989). Who's working on women in fisheries?, Naga, The ICLARM Quarterly, p.16, April.

16. Viravongsa, Duangchith (2000). Women's role in fishing communities: A case study of Xai Oudom village at the Nam Ngum reservoir, Lao PDR, master's thesis, Asian Institute of Technology.

17. Website 1: http://www.fao.org/sd/WPdirect/WPre0107.htm (downloaded on 5 August, 2002)

18. Website 2: http://www.fao.org/gender/en/fish-e.htm (downloaded on 5 August, 2002)

19. Website 3: http://www.futureharvest.org/people/fishfarming.sh $\underline{\text { tml }}$ (downloaded on 5 August 2002)

20. $\overline{Y u}$ Xiaogang (2001). Indigenous women's knowledge of sustainable fishery. In Kyoko Kusakabe and Govind Kelkar (2001), pp.27-38 